\title{
PHYSIOLOGICAL RESPONSE OF IN VITRO CULTURED MAGNOLIA SP. TO NUTRIENT MEDIUM COMPOSITION
}

\author{
Rossen S. SOKOLOV, Bistra Y. ATANASSOVA, Elena T. IAKIMOVA* \\ Institute of Ornamental Plants \\ 1222 Negovan, Sofia, Bulgaria
}

Received: March 16, 2014; Accepted: April 14, 2014

\begin{abstract}
The objective of this study was to assess the regeneration response of in vitro cultured Magnolia $\times$ soulangeana 'Alexandrina' and Magnolia liliiflora 'Nigra' to nutrient medium composition. In the primary culture (initiated from dormant axillary buds) combinations of Murashige and Skoog (MS) basal salts with 6-benzylaminopurine and $\alpha$-naphthaleneacetic acid were tested. The primary explants of cv. 'Alexandrina' expressed higher regeneration rate than cv. 'Nigra'. For both species, the regeneration was most strongly potentiated at addition of $0.25 \mathrm{mg} \cdot \mathrm{dm}^{-3}$ of the cytokinin alone. The auxin exerted undesirable effects. Several basal salts media were applied in proliferation stage and their physiological effects were evaluated in reference to traditionally used MS. At culturing on Chée \& Pool C2d Vitis Medium (VM) that is for the first time introduced to magnolia and on MS, M. liliiflora formed more but less elongated shoots than M. soulangeana. However, on VM, substantial increase (25-30\%) of the number of axillary shoots and leaves, shoot length and fresh and dry weights over MS was established for both species. This suggested VM as promising composition of nutrients in multiplication stage. Microshoots obtained on MS, VM, Rugini Olive Medium and DKW Juglans Medium were successfully rooted in vitro and subsequently established ex vitro. The findings expand the information on magnolia response to culture conditions and contribute to elaboration of innovative elements of protocols for establishing tissue cultures with high regeneration capacity.
\end{abstract}

Key words: Magnolia sp., basal medium, plant growth regulators, primary culture, rooting, shoot proliferation

\section{INTRODUCTION}

The plants from family Magnoliaceae, genus Magnolia L. (consisting of over 250 species) are flowering deciduous or evergreen trees and shrubs cultivated in sub-tropical and temperate climates (Callaway 1994; Figlar \& Nooteboom 2004). For their attractive ornamental qualities magnolias are highly demanded for landscaping purposes. Conventionally, magnolia is propagated through seeds, grafting and rooting of stem cuttings but the germination rate of the seeds is relatively low and the cuttings often express poor rooting ability (Callaway 1994; Ming \& Huan-Cheng 2003). For obtaining large amount of disease-free and genetically identical planting material, clonal micropropagation has been introduced as appropriate approach. Among the genotypes of commercial interest, the research has addressed in vitro growth response mainly of saucer magnolia (Magnolia $\times$ soulangeana), a hybrid of M. denudata $\times$ M. liliiflora, star magnolia (Magnolia stellata), hybrids from the series of Magnolia 'Little Girl' (M. liliiflora $\times$ M. stellata), and the yellowblooming magnolias (crosses between $M$. accuminata and M. heptapeta) (Biedermann 1987; Callaway 1994; Tubesing 1998; Kamenická \& Lanaková 2000; Parris et al. 2012; Radomir 2012). More broadly studied are Magnolia sp. with pharmacological properties and serious effort is paid to in vitro conservation of the gene pool of rare and endangered genotypes (Merkle \& Wiecko 1990; Callaway 1994; Parris et al. 2012 and references therein). 
Different morphogenetic capacity has been established for primary explants (apical or axillary buds) sampled from $M . \times$ soulangeana, $M$. stellata and yellow-flowering hybrids (Biedermann 1987; Kamenická \& Lanaková 2000; Tubesing 1998; Parris et al. 2012; Radomir 2012). It has also been demonstrated that in vitro growth and development of magnolias is dependent on exogenous supply of plant growth regulators (PGRs) and the requirements for the type, concentration and ratio of the hormones vary between the stages of initiation, multiplication and rooting (Biedermann 1987; Gabryszewska 1997; Kamenická \& Valka 1997; Kamenická 1998; Kamenická \& Lanaková 2000; Podwyszyńska et al. 2000; Kamenická et al. 2001; Zefang et al. 2003; Marinescu 2008; Radomir \& Radu 2008, Parris et al. 2012; Radomir 2012). For example, purine and non-purine cytokinins have been shown to exert different physiological effects. Gabryszewska (1997) reported that 6-benzylaminopurine (BAP) supplemented to Murashige and Skoog (MS) basal salts mixture stimulated the formation of axillary shoots in $M . \times$ soulangeana whereas kinetin, 6-( $\gamma, \gamma$-dimethylallylamino) purine (2iP) and phenylurea cytokinin thidiazuron [TDZ, Nphenyl-NO-(1,2,3-thidiazol-5-yl) urea] did not promote shoot regeneration. Similar influence of these cytokinins has been established on $M$. stellata and Magnolia 'Ann' (M. liliiflora 'Nigra' $\times$ M. stellata 'Rosea') (Parris et al. 2012; Radomir et al. 2012). Microcuttings of $M . \times$ soulangeana produced on MS medium containing meta-topolin [6-(3-hydroxybenzylamino) purine] - a non-purine aromatic compound with cytokinin activity have been found to express better rooting potential and higher survival rate ex vitro in comparison to rooted explants derived from MS supplemented with equimolar concentration of BAP (Podwyszyńska et al. 2000). Improvement of proliferation rate has been reported in complex media comprising combinations of BAP, $\alpha$-naphthalene-acetic acid (NAA) or indole-3acetic acid (IAA), gibberellin $\left(\mathrm{GA}_{3}\right)$, ascorbic acid and 2-(N-morpholino) ethanesulfonic acid (MES) or NaFeEDTA (Gabryszewska 1997; Podwyszyńska et al. 2000; Parris et al. 2012; Radomir 2012). In rooting stage, genotype-specific response to the concentration of indole-3-butyric acid (IBA) has been determined (Kamenická \& Lanaková 2000; Podwyszyńska et al. 2000; Parris et al. 2012; Radomir 2012).

The physiological performance of in vitro cultured magnolia is suggested to be influenced by basal salts medium composition. Biedermann (1987) has determined higher proliferation rate and better overall quality of microplants of $M$. 'Elizabeth', M. 'Yellow Bird', M. 'Cultivar \# 149' and M. stellata grown on MS in comparison to culturing on Anderson's Rhododendron Medium (RM). Kamenická \& Lanaková (2000) reported that the number of microshoots developed on $M . \times$ soulangeana propagated on modified S-medium (Standardi \& Catalano 1985) and $1 / 2$ (half strength) S-medium was almost doubled compared to McCown Woody Plant Medium (WPM) and $1 / 2$ WPM. Different growth response of $M$. 'Ann' has been observed on basal MS, 1/2 MS, WPM, Blaydes Modified Basal Salts Medium (Blaydes) (Blaydes 1966) and Driver $\&$ Kuniyuki basal salts mixture (DKW) (Parris et al. 2012). Lepoivre basal medium (Quoirin \& Lepoivre 1977) has been reported as efficient for micropropagation of M. × soulangeana (De Proftet al. 1985). For in vitro culturing of shoot apexes of M. obovata Nakamura et al. (1995) tested MS, Linsmaier and Skoog, WPM and broad-leaved tree (BT) basal media and their modifications in a primary culture of shoot apex and found that WPM and BT were not effective for the flushing of shoot apex whereas it was strongly promoted on medium containing one fourth nitrate of $1 / 2 \mathrm{MS}(1 / 4-1 / 2 \mathrm{MS})$.

Taken together, the studies indicate that for establishing of magnolia tissue cultures with high regeneration capacity, the culture conditions need to be optimised for the particular species and cultivar and stage of culture development.

The aim of this work was to assess the physiological performance of in vitro cultured M. liliiflora 'Nigra' and $M . \times$ soulangeana 'Alexandrina' in dependence on the components of nutrient medium and to select appropriate compositions for establishing tissue cultures with increased regeneration capacity. To achieve the goal, in initiation stage, the effect of combinations of MS with BAP and NAA on regeneration of primary explants (dormant axillary buds) was assessed. In multiplication stage the 
influence of several basal salts media, some of which for the first time tested for magnolia micropropagation was evaluated in reference to the traditionally used MS. The regeneration response of microplants propagated on MS, WPM, RM, Driver \& Kuniyuki Juglans medium (DKW), Chée \& Pool C2d Vitis Medium (VM), Olive Medium (OM), Gamborg B5 Medium (B5), Westvaco medium (WV3) and MS was characterized by shoot and leaf development and, accumulation of FW and DW. The processes of in vitro rooting and ex vitro acclimatization of plantlets were also addressed.

\section{MATERIALS AND METHODS}

\section{Primary explants preparation}

The experiments were undertaken with M. × soulangeana Soul.-Bod. cv. 'Alexandrina' and $M$. liliiflora Desr., cv. 'Nigra'. In vitro culture was initiated from dormant axillary buds sampled in the month of February from 15-years-old M. $\times$ soulangeana 'Alexandrina' and from 50-years-old M. liliiflora 'Nigra', growing in urban areas in cities in Middle South Bulgaria. One-year old, about $20 \mathrm{~cm}$ long apical shoots (Fig. 1a), were collected from the plants and transferred to laboratory. For removing rough contaminants, the shoots were three times rinsed with distilled water, dried on a filter paper and transferred to sterile conditions in laminar flow cabinet. The buds (Fig. 1b) were separated from the branches by using a scalpel and surface sterilized with immersing in $0.1 \% \mathrm{HgCl}_{2}$ for $3 \mathrm{~min}$ followed by triple rinsing with sterile distilled water for 10 min as described by Kamenická \& Lanaková (2000) with slight modification. Thereafter the buds were left to dry on sterile filter paper in the flow cabinet. Subsequently, with the aid of forceps and scalpel, the external wrapping of the buds and residues of wood tissue at the base of explants were removed. The in this way prepared primary explants (Fig. 1c) were placed onto introductory medium for regeneration.

\section{Establishment of primary culture}

To select appropriate medium for culture initiation, combinations of $0.25,0.5$ and $1.0 \mathrm{mg} \cdot \mathrm{dm}^{-3}$ BAP and $0.25 \mathrm{mg} \cdot \mathrm{dm}^{-3}$ NAA supplemented to MS basal salts with vitamins were tested. The media were enriched with $30 \mathrm{~g} \cdot \mathrm{dm}^{-3}$ sucrose, solidified with $7 \mathrm{~g} \cdot \mathrm{dm}^{-3}$ agar and $\mathrm{pH}$ was adjusted to 5.8 with $0.1 \mathrm{~N} \mathrm{NaOH}$ or $0.1 \mathrm{M} \mathrm{HCl}$. The media were then autoclaved at $121{ }^{\circ} \mathrm{C}$ at $1.04 \mathrm{~kg} \cdot \mathrm{cm}^{-2}$ pressure for 20 min. Single explants (altogether $100=50$ buds per variant in 2 replicates for each variant of the medium) were placed in individual sterile glass culture tubes covered with aluminium foil and the experiments were repeated two times. The tubes were maintained under room temperature $25 \pm 2{ }^{\circ} \mathrm{C}$, photoperiod day/night $16 / 8$ and $50 \mu \mathrm{mol} \cdot \mathrm{m}^{-2} \cdot \mathrm{s}^{-1}$ light intensity provided by $40 \mathrm{~W}$ cool white fluorescent tubes (Philips, Bulgaria). Regeneration rate was scored by the number of explants that developed stems and leaves and is presented in average percentage regenerated explants of 200 individual primary explants in total.

\section{Shoot proliferation}

To study the effect of basal salts medium on the process of multiplication, 60 days after culture initiation, nodal segments approximately 4 to $5 \mathrm{~mm}$ long with one leaf were separated from microshoots regenerated on MS supplemented with $0.25 \mathrm{mg} \cdot \mathrm{dm}^{-3}$ BAP and transferred onto multiplication media containing different basal salts. Segments with apical bud were not used. Eight commercially available (Duchefa, The Netherlands) basal salts media with vitamins (Table 1) were tested: MS (Murashige \& Skoog 1962), RM (Anderson 1980), B5 (Gamborg et al. 1968), VM (Chée \& Pool 1987), WPM (Lloyd and McCown 1980), DKW (Driver and Kuniyuki 1984), OM (Rugini 1984) and WV3 (Patent, Coke 1996).

The amounts of basal medium in nutrient mixtures were as recommended in manufacturer manuals: $4.4 \mathrm{~g} \cdot \mathrm{dm}^{-3} \mathrm{MS}, 2 \mathrm{~g} \cdot \mathrm{dm}^{-3} \mathrm{RM}, 3.2 \mathrm{~g} \cdot \mathrm{dm}^{-3} \mathrm{~B} 5$, $4.5 \mathrm{~g} \cdot \mathrm{dm}^{-3} \mathrm{VM}, 2.5 \mathrm{~g} \cdot \mathrm{dm}^{-3} \mathrm{WPM}, 5.6 \mathrm{~g} \cdot \mathrm{dm}^{-3} \mathrm{DKW}$, $4.2 \mathrm{~g} \cdot \mathrm{dm}^{-3} \mathrm{OM}$ and $4.3 \mathrm{~g} \cdot \mathrm{dm}^{-3} \mathrm{WV} 3$. All basal media were supplemented with $0.5 \mathrm{mg} \cdot \mathrm{dm}^{-3}$ BAP, $0.25 \mathrm{mg} \cdot \mathrm{dm}^{-3} \mathrm{NAA}$ and $30 \mathrm{~g} \cdot \mathrm{dm}^{-3}$ (determined in a separate experiment), sucrose and solidified with $7 \mathrm{~g} \cdot \mathrm{dm}^{-3}$ agar. Media $\mathrm{pH}$, autoclaving and environmental conditions were as described above for culture initiation. The explants were grown in $400 \mathrm{ml}$ glass vessels in which the medium quantity was equalized to $60 \mathrm{ml}$ by using automatic Ismatec ISM404B MCP Pump (ISMATEC, Switzerland). 
The vessels were tightly covered with metal screw cups. For each separate variant of the basal medium, 50 nodal segments, distributed in 10 replicates, each replicate containing 5 explants per vessel were used.
The experiment was repeated three times. The subculturing was performed every 60 days onto the same media and by using the same type of nodal segments.
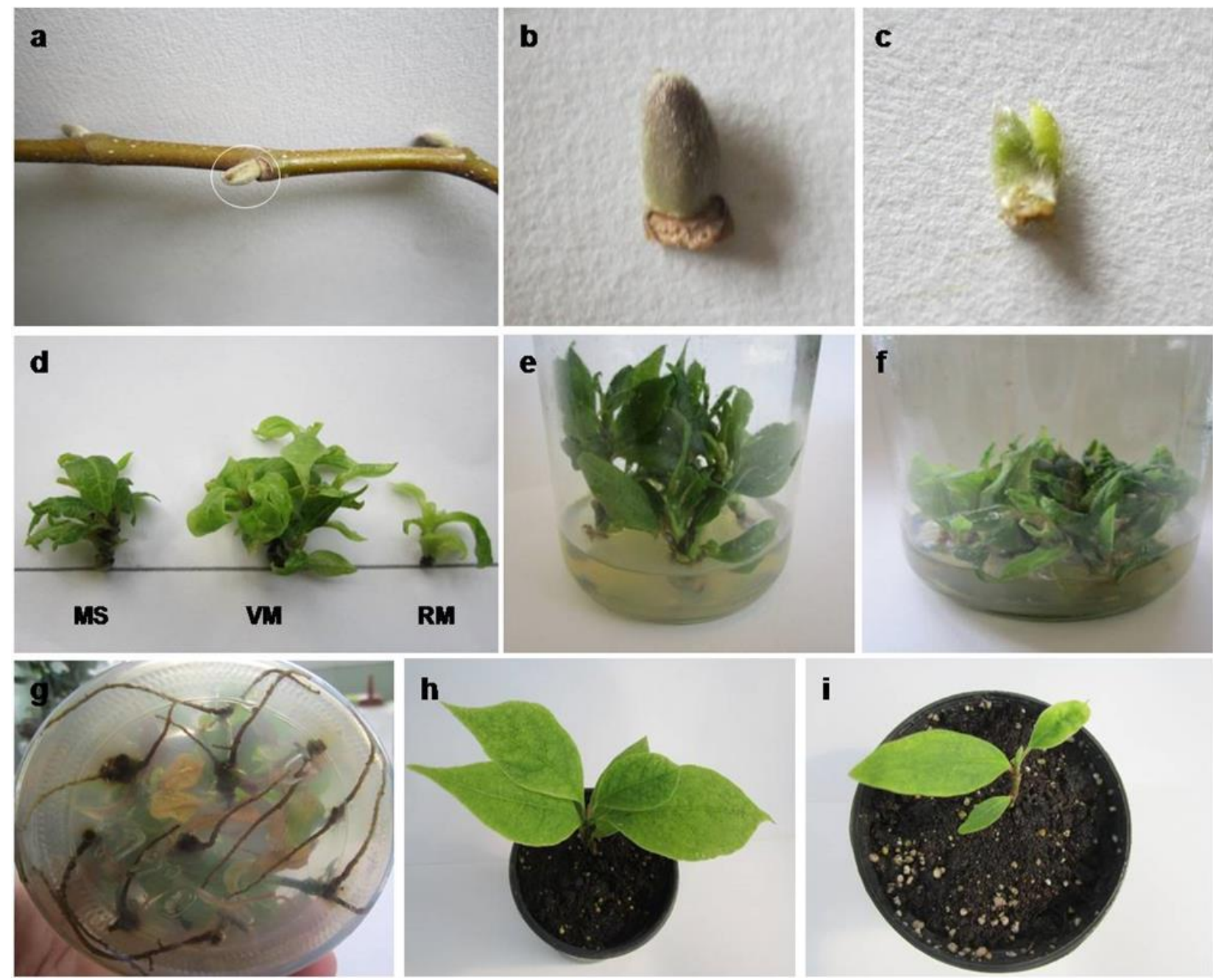

Fig. 1. Representative images of consecutive stages of in vitro propagation of magnolia

a. Axillary buds of $M . \times$ soulangeana 'Alexandrina' attached to apical shoot; $\mathbf{b}$. isolated axillary bud of M. soulange$a n a ;$ c. primary explants of $M$. soulangeana with removed wrapping, Note: the axillary buds and the primary explants of $M$. soulangeana and $M$. liliiflora look almost identically; d. sixty-days-old individual explants of $M$. soulangeana propagated on MS, VM and RM; e. sixty-days-old culture of $M . \times$ soulangeana and $\mathbf{f}$. M. liliiflora grown on VM medium; g. In vitro rooted explants of $M . \times$ soulangeana after 60 days in rooting medium, Note: the rooted explants of $M$. liliiflora appear morphologically similar to $M$. soulangeana and are not shown; $\mathbf{h}$. sixty-days-old acclimatized plants derived from in vitro culture of $M . \times$ soulangeana; i. M. Liliiflora. MS = Murashige \& Skoog medium; $\mathrm{VM}=$ Chée \& Pool C2d Vitis Medium; RM = Anderson's Rhododendron Medium. 
Table 1. Compositions of basal salts media

\begin{tabular}{|c|c|c|c|c|c|c|c|c|}
\hline Compound & MS & $\mathrm{RM}$ & B5 & VM & WPM & DKW & $\mathrm{OM}$ & WV3 \\
\hline \multicolumn{9}{|l|}{ Macroelements (mM) } \\
\hline $\mathrm{CaCl}_{2}$ & 2.99 & 2.99 & 1.02 & & 0.65 & 1.01 & 2.99 & 4.08 \\
\hline $\mathrm{KNO}_{3}$ & 18.79 & 4.75 & 24.73 & 18.79 & & & 10.88 & 9.00 \\
\hline $\mathrm{K}_{2} \mathrm{SO}_{4}$ & & & & & 5.68 & 8.95 & & \\
\hline $\mathrm{KCl}$ & & & & & & & 6.71 & 8.81 \\
\hline $\mathrm{KH}_{2} \mathrm{PO}_{4}$ & 1.25 & & & 1.25 & 1.25 & 1.95 & 2.50 & 1.98 \\
\hline $\mathrm{NaH}_{2} \mathrm{PO}_{4}$ & & 2.75 & 1.09 & & & & & \\
\hline $\mathrm{MgSO}_{4}$ & 1.50 & 1.50 & 1.01 & 1.5 & 1.50 & 3.00 & 6.09 & 7.51 \\
\hline $\mathrm{NH}_{4} \mathrm{NO}_{3}$ & 20.61 & 5.00 & & 20.61 & 5.00 & 17.70 & 5.15 & \\
\hline $\mathrm{Ca}\left(\mathrm{NO}_{3}\right)_{2} 2 \mathrm{H}_{2} \mathrm{O}$ & & & & 2.99 & 2.35 & 8.30 & 2.54 & \\
\hline$\left(\mathrm{NH}_{4}\right)_{2} \mathrm{SO}_{4}$ & & & 1.01 & & & & & \\
\hline \multicolumn{9}{|l|}{ Microelements $(\boldsymbol{\mu M})$} \\
\hline $\mathrm{CoCl}_{2} 6 \mathrm{H}_{2} \mathrm{O}$ & 0.11 & 0.11 & 0.11 & 0.11 & & & 0.11 & 0.11 \\
\hline $\mathrm{CuSO}_{4} 5 \mathrm{H} 2 \mathrm{O}$ & 0.10 & 0.10 & 0.10 & 0.10 & 1.00 & 1.00 & 1.00 & 1.00 \\
\hline $\mathrm{H}_{3} \mathrm{BO}_{3}$ & 100 & 100 & 48.52 & 100 & 100 & 77.63 & 200 & 500 \\
\hline $\mathrm{KI}$ & 5.00 & 1.81 & 4.52 & & & & 5 & 5 \\
\hline $\mathrm{MnSO}_{4} \mathrm{H}_{2} \mathrm{O}$ & 100.0 & 100.0 & 59.16 & 5.00 & 130.0 & 200.0 & 100.0 & 90.0 \\
\hline $\mathrm{Na}_{2} \mathrm{MoO}_{4} 2 \mathrm{H}_{2} \mathrm{O}$ & 1.03 & 1.03 & 1.03 & 1.03 & 1.03 & 1.61 & 1.03 & 1.03 \\
\hline $\mathrm{ZnSO}_{4} 7 \mathrm{H}_{2} \mathrm{O}$ & 29.91 & 29.91 & 6.96 & 29.91 & 29.91 & 72.19 & 49.75 & 30.0 \\
\hline FeNa EDTA & 100.0 & 200.0 & 100.0 & 100.0 & 100.0 & 112.0 & 100.0 & 100.0 \\
\hline \multicolumn{9}{|l|}{ Vitamins $(\mu M)$} \\
\hline Adenine sulphate & & 430.0 & & & & & & \\
\hline Myoinositol & 556.0 & 556.0 & 556.0 & 55.60 & 556.0 & 556.0 & 556.0 & 5560.0 \\
\hline Thiamine hydrochloride & 0.30 & 1.19 & 29.65 & 3.00 & 2.96 & 5.93 & 1.48 & 1.19 \\
\hline Nicotinic acid & 4.10 & & 8.12 & 8.12 & 4.06 & 8.12 & 40.94 & \\
\hline Glycine & 26.64 & & & & 26.64 & 26.64 & 26.64 & \\
\hline Biotin & & & & & & & 0.20 & \\
\hline Folic acid & & & & & & & 1.13 & \\
\hline Pyridoxine hydrochloride & 2.43 & & 4.86 & & 2.43 & & 2.43 & \\
\hline
\end{tabular}

The compounds in the nutrient media are presented in final concentrations. Media full names and abbreviations: Murashige \& Skoog (MS), Anderson's Rhododendron Medium (RM), Gamborg B5 Medium (B5), Chée \& Pool C2D Vitis Medium (VM), McCown Woody Plant Medium (WPM), DKW Juglans medium (JM), Rugini Olive Medium (OM), Westvaco WV3 medium (WV3).

\section{Characterization of growth and development of explants}

Growth and development of explants during proliferation stage were evaluated after the second sub-culture. The number of lateral shoots and number of leaves produced from single explant and its length (from the level of the media to the tip of the longest shoot) were recorded. The effect of basal medium on the physiological status of microplants was also estimated by FW and DW. DW was determined after drying the samples at $80^{\circ} \mathrm{C}$ for $24 \mathrm{~h}$, then the samples were cooled, placed in a dessicator for $2 \mathrm{~h}$ and measured; thereafter transferred back to the oven for additional $24 \mathrm{~h}$ and measured again followed by subsequent measurements at intervals of $2 \mathrm{~h}$ until reaching constant weight.

\section{In vitro rooting and $e x$ vitro acclimatization}

Microshoots derived from cultures propagated on media containing MS, VM, OM or DKW basal salts were placed for rooting onto MS supplemented 
with $2 \mathrm{mg} \cdot \mathrm{dm}^{-3} \mathrm{NAA}$. The experiments were performed with 30 microplants from each basal medium (3 repetitions, each consisting of 10 microplants per Petri dish) and the whole set of experiments was repeated three times. After 60 days, explants with well-developed roots were used for acclimatization. The roots were washed for removing the traces of agar and the microplants transferred for acclimatization into plastic containers $(200 \mathrm{ml}$ volume) on substrate peat : perlite $4: 1$. For providing proper nutrient supply, commercial peat enriched with $\mathrm{N}, \mathrm{P}, \mathrm{K}$ and microelements ( $\mathrm{Fe}, \mathrm{Mn}, \mathrm{Co}, \mathrm{B}$, $\mathrm{Mg}, \mathrm{Zn}$ ); pH 6.0 (DURPETA, Lithuania) was used. The containers were plastic covered and maintained for 20 days at temperature $24-26^{\circ} \mathrm{C}$ overnight, $90 \%$ relative humidity, photoperiod day/night $14 / 10 \mathrm{~h}$, light intensity $50 \mu \mathrm{mol} \cdot \mathrm{m}^{-2} \cdot \mathrm{s}^{-1}$. The cover was regularly opened once per day for $2 \mathrm{~h}$. After the cover was removed, the plants were left for 60 days at above conditions with a difference that air humidity and temperature were reduced to $70 \%$ and $22-24{ }^{\circ} \mathrm{C}$ respectively. At day 60 , the percentage of rooted explants was determined. Thereafter the plants were established in pots (diameter $9 \mathrm{~cm}$ ) on the same substrate and grown in a greenhouse under the above conditions. For preventing rotting the plants were treated with $0.1 \%$ solution of Proplant 722 SL (Chimac Agriphar S.A., Belgium). Survival rate of acclimated plants was determined 60 days after potting.

\section{Data analysis}

Data were subjected to one-way analysis of variance (ANOVA) and Duncan's multiple range test at probability level $\mathrm{p}<0.05$ (SPSS, IBM) was used to separate treatment means. The presented values are means of all experiments $\pm \operatorname{SEM}(\mathrm{n}-1)$.

\section{RESULTS}

\section{Effect of BAP and NAA on regeneration of pri- mary explants}

On hormone-free MS medium (control), M. × soulangeana 'Alexandrina' expressed higher regeneration rate than $M$. liliiflora 'Nigra'. Same trend of differences between the genotypes was pronounced in presence of 0.25 and $0.5 \mathrm{mg} \cdot \mathrm{dm}^{-3} \mathrm{BAP}$ and the combination of these BAP concentrations with $0.25 \mathrm{mg} \cdot \mathrm{dm}^{-3} \mathrm{NAA}$. The highest number (approximately 30 and $40 \%$ over hormone-free medium) of buds from both genotypes regenerated in presence of $0.25 \mathrm{mg} \cdot \mathrm{dm}^{-3}$ BAP alone (Table 2 ). In comparison to hormone-free medium, the addition of $0.5 \mathrm{mg} \cdot \mathrm{dm}^{-3} \mathrm{BAP}+\mathrm{NAA}$ stimulated the regeneration of $M . \times$ soulangeana whereas for M. liliiflora this composition did not promote satisfactory effect. At amounts of BAP higher than $0.25 \mathrm{mg} \cdot \mathrm{dm}^{-3}$ and in presence of NAA the quality of explants of both studied genotypes was reduced due to occurrence of leaf deformations, blackening, callus formation, shortening of the shoots and symptoms of hyperhydricity. NAA alone entirely suppressed the regeneration and resulted in mass callus formation (not subjected to a statistical calculation). BAP at $1.0 \mathrm{mg} \cdot \mathrm{dm}^{-3}+$ NAA did not cause an increase of regeneration rate over the control. The observations determined $0.25 \mathrm{mg} \cdot \mathrm{dm}^{-3} \mathrm{BAP}$ as most efficient for stimulating the regeneration of the used primary explants of both cultivars (Table 2).

Table 2. Effect of BAP and NAA on in vitro regeneration of primary explants of Magnolia sp.

\begin{tabular}{|c|c|c|}
\hline \multirow{2}{*}{$\begin{array}{c}\text { MS basal salts mixture } \\
\text { BAP and NAA } \\
\text { in } \mathrm{mg} \cdot \mathrm{dm}^{-3}\end{array}$} & \multicolumn{2}{|c|}{ Regeneration (\%) } \\
\hline & $\begin{array}{c}\text { M. } \times \text { soulangeana } \\
\text { 'Alexandrina' }\end{array}$ & $\begin{array}{l}\text { M. liliiflora } \\
\text { 'Nigra' }\end{array}$ \\
\hline $\begin{array}{l}\text { Control (growth regu- } \\
\text { lator-free) }\end{array}$ & $45.0 \pm 1.6 \mathrm{~b}$ & $35.2 \pm 1.7 \mathrm{~b}$ \\
\hline $0.25 \mathrm{BAP}$ & $75.0 \pm 5.0 \mathrm{e}$ & $60.0 \pm 2.3 \mathrm{e}$ \\
\hline $0.5 \mathrm{BAP}$ & $55.4 \pm 1.9 \mathrm{c}$ & $43.3 \pm 1.3 \mathrm{c}$ \\
\hline 1.0 BAP & $30.3 \pm 3.2 \mathrm{a}$ & $33.2 \pm 2.0 \mathrm{~b}$ \\
\hline $0.25 \mathrm{BAP}+0.25 \mathrm{NAA}$ & $60 \pm 1.2 \mathrm{~d}$ & $53.3 \pm 1.2 \mathrm{~d}$ \\
\hline $0.5 \mathrm{BAP}+0.25 \mathrm{NAA}$ & $50.2 \pm 1.9 \mathrm{c}$ & $30.1 \pm 2.6 b$ \\
\hline $1.0 \mathrm{BAP}+0.25 \mathrm{NAA}$ & $25.4 \pm 2.7 \mathrm{a}$ & $30.2 \pm 4.9 b$ \\
\hline
\end{tabular}

Data are means $\pm \operatorname{SEM}(n-1)$. Values with different letters in the same column are significantly different from each other at $\mathrm{p}<0.05$.

\section{Effect of basal salts media on growth and devel- opment in multiplication stage}

For M. $\times$ soulangeana 'Alexandrina' the largest number of shoots developed when the explants 
were grown on VM and DKW media, exceeding the control MS with 44 and 28\%, respectively (Table 3 , Fig. 1d \& e). Lower number of shoots was recorded on media B5, RM, WPM and WV3 (Table 3). The effect of OM was commensurable to MS. For both genotypes cultured on VM basal salts, the number of axillary shoots exceeded MS with 30\% (Fig. 1d). For M. liliiflora 'Nigra' DKW and OM-promoted shoot formation to extent similar to MS whereas on B5, WPM and WV3 media the shoots were 15-25\% less than on MS (Table 4). On RM basal salts the number of shoots of both cv. 'Alexandrina' and cv. 'Nigra' was reduced (approximately 36\% less in comparison to MS). The effect of RM on shoot number of $M$. soulangeana is illustrated on Fig. 1d.

$M$. soulangeana 'Alexandrina' formed more elongated shoots in comparison to $M$. liliiflora 'Nigra' (Fig. 1e \& f). For both genotypes the longest shoots developed on VM, approximately 35-36\% over MS (Tables $3 \& 4$, Fig. 1d). Shoot elongation on RM, B5 and WV3 media was suppressed up to $50 \%$ in comparison to MS (Tables $3 \& 4$, Fig. 1d). WPM and DKW media appeared not to stimulate the elongation. In comparison to MS, on WV3 and RM 31-37\% inhibition of shoot growth of both genotypes was observed. On OM the shoot length of M. × soulangeana was similar to MS (Table 3) whereas for M. liliiflora it slightly exceeded the control (Table 4).

The number of leaves developed on both Magnolia genotypes was most positively influenced by VM basal salts - approximately 35\% over MS and did not substantially differ between the genotypes. For explants cultured on DKW the leaf number was similar to MS. RM, B5 and WV3 media did not stimulate leaf development - the leaf number was 25$50 \%$ of that on MS medium (Tables $3 \& 4$, Fig. 1d). For cv. 'Nigra' slight stimulation of leaf growth over the control was observed on OM whereas for cv. 'Alexandrina' this medium appeared to inhibit the leaf development (Tables $3 \& 4$ ). Comparative evaluation of the species response, especially to MS and VM revealed that $M . \times$ soulangeana formed lower number but longer shoots than M. liliiflora (Tables 3 \& 4, Fig. $1 d$, e \& f).

These results showed that VM basal salts most strongly affected the shoot and leaf growth and shoot elongation of both studied magnolia genotypes. The data also pointed to genotype specificity of the response to basal medium composition.

Table 3. Effect of basal salts media on growth and development in the multiplication phase of in vitro cultured $M . \times$ soulangeana 'Alexandrina'

\begin{tabular}{cccc}
\hline $\begin{array}{c}\text { Basal salts } \\
\text { medium }\end{array}$ & $\begin{array}{c}\text { Shoot } \\
\text { number }\end{array}$ & $\begin{array}{c}\text { Length of } \\
\text { longest } \\
\text { shoot }(\mathrm{mm})\end{array}$ & $\begin{array}{c}\text { Leaf } \\
\text { number }\end{array}$ \\
\hline MS & $2.9 \pm 0.1 \mathrm{~b}$ & $32.9 \pm 0.6 \mathrm{~d}$ & $13.7 \pm 0.4 \mathrm{~d}$ \\
RM & $1.9 \pm 0.1 \mathrm{a}$ & $13.9 \pm 0.4 \mathrm{a}$ & $7.4 \pm 0.3 \mathrm{a}$ \\
B5 & $1.7 \pm 0.1 \mathrm{a}$ & $18.3 \pm 0.7 \mathrm{~b}$ & $6.8 \pm 0.2 \mathrm{a}$ \\
VM & $4.2 \pm 0.2 \mathrm{~d}$ & $44.3 \pm 0.8 \mathrm{e}$ & $18.4 \pm 0.5 \mathrm{e}$ \\
WPM & $2.1 \pm 0.1 \mathrm{a}$ & $241 \pm 0.7 \mathrm{c}$ & $9.2 \pm 0.3 \mathrm{~b}$ \\
DKW & $3.7 \pm 0.2 \mathrm{c}$ & $25.7 \pm 0.4 \mathrm{c}$ & $13.1 \pm 0.4 \mathrm{~d}$ \\
OM & $2.5 \pm 0.1 \mathrm{~b}$ & $34.5 \pm 0.8 \mathrm{~d}$ & $11.1 \pm 0.4 \mathrm{c}$ \\
WV3 & $1.9 \pm 0.1 \mathrm{a}$ & $20.3 \pm 0.7 \mathrm{~b}$ & $6.5 \pm 0.3 \mathrm{a}$ \\
\hline
\end{tabular}

For media full names, please, refer to Table 1. Data are means \pm SEM (n-1). Values with different letters in the same column are significantly different from each other at $\mathrm{p}<0.05$.

Table 4. Effect of basal salts media on growth and development in the multiplication phase of in vitro cultured M. liliiflora 'Nigra'

\begin{tabular}{cccc}
\hline $\begin{array}{c}\text { Basal salts } \\
\text { medium }\end{array}$ & $\begin{array}{c}\text { Shoot } \\
\text { number }\end{array}$ & $\begin{array}{c}\text { Length of } \\
\text { longest } \\
\text { shoot }(\mathrm{mm})\end{array}$ & $\begin{array}{c}\text { Leaf } \\
\text { number }\end{array}$ \\
\hline MS & $4.6 \pm 0.1 \mathrm{c}$ & $18.6 \pm 0.3 \mathrm{c}$ & $12.7 \pm 0.2 \mathrm{c}$ \\
RM & $3.0 \pm 0.1 \mathrm{a}$ & $12.9 \pm 0.3 \mathrm{a}$ & $9.5 \pm 0.2 \mathrm{~b}$ \\
B5 & $3.9 \pm 0.1 \mathrm{~b}$ & $16.3 \pm 0.24 \mathrm{~b}$ & $9.6 \pm 0.21 \mathrm{~b}$ \\
VM & $6.1 \pm 0.2 \mathrm{~d}$ & $25.4 \pm 0.4 \mathrm{e}$ & $17.2 \pm 0.3 \mathrm{e}$ \\
WPM & $4.0 \pm 0.1 \mathrm{~b}$ & $17.4 \pm 0.2 \mathrm{c}$ & $10.9 \pm 0.3 \mathrm{~b}$ \\
DKW & $4.5 \pm 0.2 \mathrm{c}$ & $17.4 \pm 0.2 \mathrm{c}$ & $12.3 \pm 0.2 \mathrm{c}$ \\
OM & $4.4 \pm 0.1 \mathrm{c}$ & $22.7 \pm 0.3 \mathrm{~d}$ & $13.7 \pm 0.3 \mathrm{~d}$ \\
WV3 & $3.5 \pm 0.1 \mathrm{~b}$ & $11.8 \pm 0.4 \mathrm{a}$ & $6.6 \pm 0.2 \mathrm{a}$ \\
\hline
\end{tabular}

For media full names, please, refer to Table 1. Data are means \pm SEM (n-1). Values with different letters in the same column are significantly different from each other at $\mathrm{p}<0.05$. 

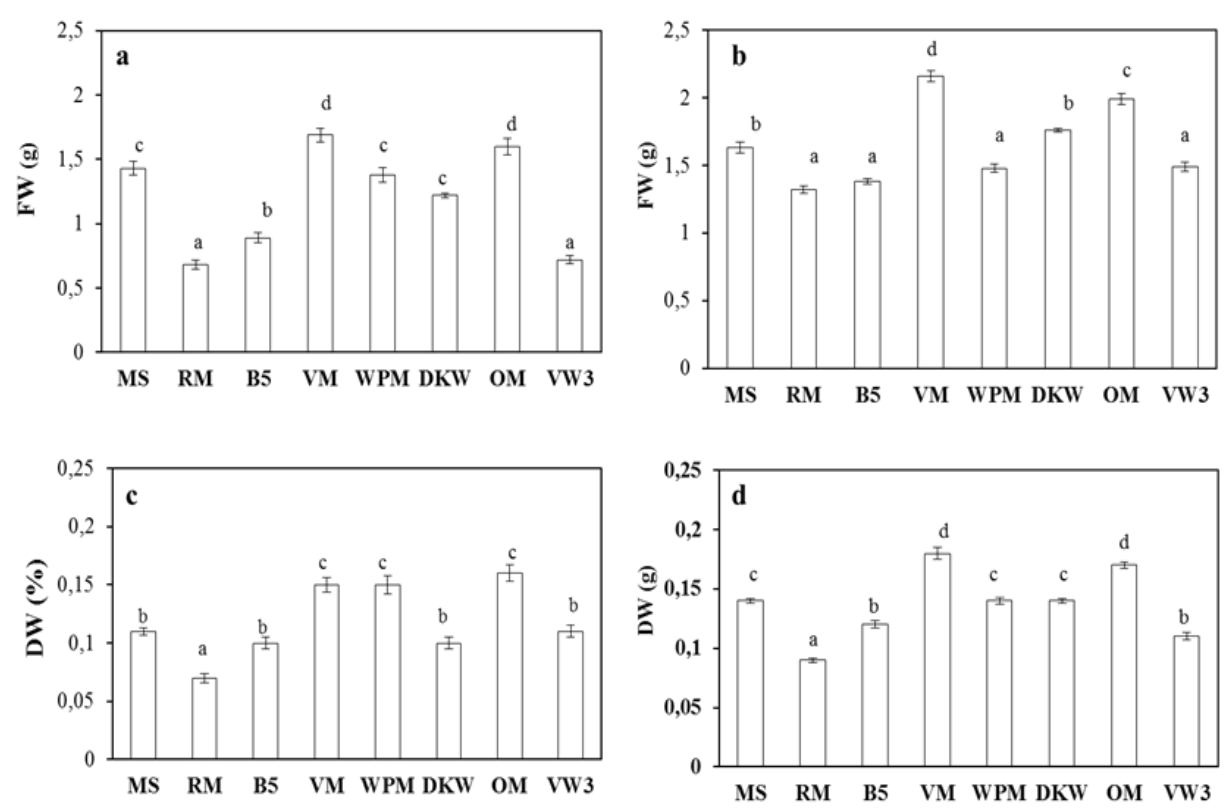

Fig. 2. Effect of basal salts media on fresh (FW) and dry (DW) weight of in vitro cultured M. $\times$ soulangeana 'Alexandrina' and $M$. liliiflora 'Nigra'

a. FW of M. × soulangeana; b. FW of M. liliiflora; c. DW of M. $\times$ soulangeana; $\mathbf{d} . \mathrm{DW}$ of M. liliiflora.

For media full names, please, refer to Table 1. Bars represent the mean values. Error bars indicate \pm SEM (n-1). Significant differences at $\mathrm{p}<0.05$ are indicated with different letters. FW, fresh weight; DW, dry weight

\section{Effect of basal media on FW and DW}

Highest FW of the explants from M. $\times$ soulangeana 'Alexandrina' was recorded at culturing on VM and OM media (18\% and $11 \%$ more than on MS). Similar FW to that of explants propagated on MS was obtained on WPM and DKW. Media RM, B5 and WV3 did not potentiate the accumulation of FW which remained up to approximately $50 \%$ from that in the control (Fig. 2a). For M. liliiflora 'Nigra', FW of the explants was increased on VM, exceeding the MS control with $32 \%$ and on OM with app. $22 \%$. DKW medium exerted same effect as MS. More stimulating influence of $\mathrm{OM}$ on FW of M. liliiflora 'Nigra' as compared to $M$. × soulangeana 'Alexandrina' was observed. The explants of $M$. liliiflora 'Nigra' grown on RM, B5, WPM and WV3 had significantly lower FW than those grown on MS (Fig. 2b).

An increase of DW was established when M. × soulangeana 'Alexandrina' explants were cultured on OM, VM and WPM media; DW of explants grown on DKW, B5 and WV3 did not differ from MS; the explants propagated on RM accumulated significantly less dry mass than the explants on MS (Fig. 2c). Increased DW of M. liliiflora 'Nigra' was measured on VM and OM, respectively, 27\% and $20 \%$ more than the control. On WPM and DKW media DW was commensurable to MS. On RM, B5 and WV3 a decrease of DW was detected (Fig. 2d).

These results indicated that in reference to MS, $\mathrm{VM}$ and OM media stimulated the accumulation of fresh and dry mass of the explants from both genotypes whereas the other tested media provided none or inhibitory effect.

\section{In vitro rooting and $e x$ vitro acclimatisation}

The first roots appeared after 20 days. Sixty days after the transfer, $84 \%$ of $M . \times$ soulangeana 'Alexandrina' and $98 \%$ of $M$. liliiflora 'Nigra' formed well-microshoots developed roots (Fig. 1g). No difference in the rooting potential of explants derived from different basal media was observed. From in vitro rooted plants of both genotypes $97 \%$ were successfully acclimatised and further established in pots in greenhouse conditions (Fig. 1h \& i). 


\section{DISCUSSION}

Regeneration response of primary explants is genotype specific and is modified by $B A P$ and NAA

Studies on the effects of PGRs on proliferation and rooting of in vitro cultured magnolias have pointed to genotype-specific requirements (Biedermann 1987; Gabryszewska 1997; Kamenická \& Valka 1997; Kamenická 1998; Kamenická \& Lanaková 2000; Podwyszyńska et al. 2000; Kamenická et al. 2001; Zefang et al. 2003; Marinescu 2008; Radomir \& Radu 2008; Parris et al. 2012). However, few works have addressed the genotype specificity of the performance of primary explants in initiation stage. Radomir (2012) has found that independently on the type, concentration and ratio of PGRs in introductory medium, dormant axillary buds of $M$. stellata expressed higher regeneration rate in comparison to $M . \times$ soulangeana. Our observations showed that the regeneration potential of primary explants of $M$. soulangeana and M. liliiflora also differed between the genotypes: cv. 'Alexandrina' produced more regenerated buds than cv. 'Nigra'. The response was modified by BAP and NAA with the highest regeneration rate in the presence of $0.25 \mathrm{mg} \cdot \mathrm{dm}^{-3}$ BAP. NAA induced undesirable callus formation. The established effects of these two hormones are to some extent in line with the findings of Nakamura et al. (1995). These authors tested various concentrations of BAP, NAA and IBA supplemented to $1 / 4 \mathrm{~N}-1 / 2$ MS used for establishing of primary culture of shoot apex of M. obovata. They reported that 1-5 $\mu$ mol BAP $\left(0.25-1.25 \mathrm{mg} \cdot \mathrm{dm}^{-3}\right)$ in combination with $0.1 \mu \mathrm{mol}$ IBA (approximately $0.02 \mathrm{mg} \cdot \mathrm{dm}^{-3}$ ) most efficiently stimulated the shoot elongation after bud flushing whereas BAP alone induced bud flushing but not shoot elongation. Higher concentrations of $10 \mu \mathrm{mol}$ BAP $\left(2.5 \mathrm{mg} \cdot \mathrm{dm}^{-3}\right)$ caused browning. Additionally, they showed that NAA even at low concentrations caused browning of the explants and callus formation. We found that in the initiation stage of culturing only $0.25 \mathrm{mg} \cdot \mathrm{dm}^{-3} \mathrm{BAP}(1 \mu \mathrm{mol})$ is sufficient for promoting the formation of stems and leaves from nodal buds of both magnolia genotypes.

\section{Composition of basal salts medium affects growth performance of explants during proliferation stage}

In an effort to elaborate improved protocols for establishing cultures with high potential for in vitro proliferation, we have tested the physiological effects of several basal salts media including such that have not been earlier applied to Magnolia sp. In previously reported works, some of the effects of basal salts mixtures MS, WPM, DKW and RM on in vitro performance of magnolia have been described (Biedermann 1987; Kamenická \& Lanaková 2000; Parris et al. 2012; Radomir 2012), but to the best of our knowledge, in the reported study, VM, OM, B5 and WV3 were introduced for the first time. Kamenická \& Lanaková (2000) have observed morphological differences of microplants grown on WPM and S-medium. On WPM, the leaves were smaller and the stems shorter with increased number of nodes; on S- medium more shoots with elongated internodes were formed and the leaves appeared larger and more succulent. By comparing MS and DKW media Parris et al. (2012) showed that the highest number of shoots developed on full strength MS whereas DKW-simulated shoot elongation; fresh and dry weights of explants increased at culturing on $1 / 2$ MS.

The studies have also indicated that various basal salts media can be successfully administrated for micropropagation of species taxonomically distant from the ones for which the medium has been originally elaborated (de Oliveira et al. 2011; Durković 2003; Fernándes-Lorenzo et al. 2000; Fett-Neto et al. 1993; Harada \& Murai 1996; Orlikowska \& Gabryszewska 1995; Phelan et al. 2009; Shanjani 2003; Zhang et al. 2000). Therefore, we hypothesize that media non-traditional for magnolia could be appropriate and might improve the regeneration performance of in vitro grown magnolia.

It has been shown that independently on basal medium composition, for efficient proliferation of Magnolia sp. cytokinins and auxins are strongly required (Biedermann 1987, Kamenická \& Lanaková 2000; Parris et al. 2012; Radomir 2012). We have also established that when the media were not supplemented with BAP and NAA the regeneration in multiplication stage was prevented (data not 
shown). An interesting observation was that whereas in initiation stage only $0.25 \mathrm{mg} \cdot \mathrm{dm}^{-3} \mathrm{BAP}$ was sufficient for the growth of primary explants, in multiplication stage higher concentration of BAP and compulsory the addition of NAA were required. In order to distinguish the influence of basal medium by possibly ignoring the effects exerted by exogenously added PGRs, the media were supplemented with same concentrations of BAP and NAA.

MS basal salts medium has been commonly used for in vitro propagation of various magnolia genotypes (Biedermann 1987; Kamenická \& Lanaková 2000; Podwyszyńska et al. 2000; Parris et al. 2012; Radomir 2012). For this reason, in our experiments MS was selected as control basal medium. Comparative assessment of magnolia growth response to MS, DKW, WPM, Blaydes medium and RM has shown highest efficiency of MS (Biedermann 1987; Parris et al. 2012). In line with these finding, our data also show satisfactory proliferation rate on MS. In addition, we determined an advantage of MS over WPM and RM and over the non-traditional for magnolia B5 and WV3 media.

VM basal salts most substantially stimulated the growth and development of both $M . \times$ soulangeana 'Alexandrina' and M. liliiflora 'Nigra' including the formation of axillary shoots and leaves, shoot elongation and augmentation of FW and DW. On MS, multiplication rate and FW and DW were in general $30 \%$ lower than at culturing on VM. VM is routinely used for micropropagation of grape varieties (Chée \& Pool 1987; Gray \& Benton 1991; Dutt et al. 2007) but is also reported as appropriate for in vitro culturing of plum, apricot and other fruit trees (Burgos \& Ledbetter 1993; Emershad \& Ramming 1994). Here we demonstrate that VM can be administrated for micropropagation of $M . \times$ soulangeana 'Alexandrina' and M. liliiflora 'Nigra'. The obtained results give us a reason to propose VM as potential novel composition of nutrient medium for in vitro multiplication stage of magnolia. In our laboratory, evaluation of the applicability of VM to in vitro cultures of other magnolia genotypes is in progress.

DKW is known for in vitro propagation of walnuts, ash, elm, hazel bush, olive tree and hornbeam (Driver \& Kuniyuki 1984; Chalupa 1990; Hammatt \& Ridout 1992; Fenning et al. 1993; Yu \& Reed
1993; Tang et al. 2000; Santos et al. 2003). According to Parris et al. (2012), DKW was less effective than MS for in vitro propagation of $M$. 'Ann'. Our data indicated that for both studied genotypes, DKW promoted shoot and leaf formation and accumulation of FW and DW to extent commensurable to MS whereas the shoot elongation of $M . \times$ soulangeana was suppressed. OM basal salts have been initially developed for micropropagation of olive tree (Rugini 1984; Rugini \& Caricato 1995). In our experiments it was for the first time tested for magnolia culturing. We have established that $\mathrm{OM}$ positively affected the growth and development in similar to MS manner. Moreover, on OM, FW and DW of explants were comparable to VM.

Basal media RM, WV3, WPM and B5 appeared inappropriate for studied genotypes. Our results for WPM and RM substantiate the literature data that these basal mixtures are not advantageous over MS for other magnolia cultivars (Biedermann 1987; Kamenická \& Lanaková 2000; Parris et al. 2012). B5 has been elaborated for suspension cultures of soybean root cells (Gamborg et al. 1968) and WV3 has been elaborated for in vitro culturing of loblolly pine (Coke 1996). No information for testing B5 and WV3 media on magnolia could be found. Our data indicate that they are inefficient for improving the in vitro proliferation of studied genotypes.

The presented results clearly demonstrate that the composition of basal salts medium is an important factor affecting the physiological performance of in vitro cultured magnolia. The applied media differ in the type of salts and concentrations of macro- and microelements, and vitamins. Limited studies are available on the influence of individual macro- and microelements and vitamins on micropropagation of Magnolia sp. Biedermann (1987) has established that $120 \mathrm{mg} \cdot \mathrm{dm}^{-3} \mathrm{KNO}_{3}$ added to MS-promoted optimum rate of multiplication of $M$. 'Yellow Bird' and M. 'Cultivar \#149' whereas $240-480 \mathrm{mg} \cdot \mathrm{dm}^{-3}$ were necessary for M. 'Elizabeth' and $480 \mathrm{mg} \cdot \mathrm{dm}^{-3} \mathrm{KNO}_{3}$ were required for $M$. stellata. Higher amount of $1900 \mathrm{mg} \cdot \mathrm{dm}^{-3} \mathrm{KNO}_{3}$ has been found toxic. Analysis of accumulation of $\mathrm{K}, \mathrm{Ca}, \mathrm{Na}, \mathrm{Zn}, \mathrm{Mn}, \mathrm{Fe}$ and $\mathrm{Cu}$ in M. $\times$ soulangeana explants cultured on S-medium 
have shown that the content of these elements dynamically changes in the course of explants development. Essential role of $\mathrm{Ca}$ and $\mathrm{K}$ for growth stimulation has been suggested (Valova et al. 1996). In addition to Murashige \& Skoog vitamins, other compositions such as Linsmaier \& Skoog vitamins (Linsmaier \& Skoog 1965), Miller vitamins (Miller 1978) have been used in conjunction with MS or RM basal salts (Beidermann 1987; Radomir 2012) but the specific effects have not been described.

Our findings provide novel information on magnolia growth response to non-traditional for these species basal salts and pose further questions on the impact of individual components of basal media, their uptake and utilization in plant tissues.

\section{In vitro rooting and acclimatization ex vitro}

Our data showed that on MS with $2 \mathrm{mg} \cdot \mathrm{dm}^{-3}$ NAA the rooting capacity of explants derived from cultures propagated on media containing MS, VM, DKW or OM basal salts did not differ. This suggests that the rooting potential of explants was probably not affected by basal salts composition. During acclimatisation stage and after establishment in pots, a large proportion of in vitro derived rooted microplants survived and grew well. This demonstrates that the suggested novel nutrient media are applicable for producing high-quality planting material of the studied magnolia genotypes.

The reported findings expand the information on the physiological response of studied magnolia genotypes to in vitro culture conditions and contribute to elaboration of protocols for establishment of highly productive tissue cultures.

\section{CONCLUSIONS}

In summary, the results obtained from this study show that:

1. Regeneration response of $M . \times$ soulangeana 'Alexandrina' and M. liliiflora 'Nigra' to in vitro culture conditions in initiation and multiplication stages occurs in genotype-specific manner.

2. The physiological performance of studied magnolia species was affected by basal salts media composition.
3. The non-traditional for magnolia basal medium VM substantially improved the growth and development resulting in increased proliferation rate and overall better quality of the microplants in comparison to conventionally used MS basal salts. Therefore VM can be proposed as efficient component of proliferation medium.

4. DKW and OM basal salts exerted similar effects as MS and are also promising for introduction in multiplication stage.

\section{Acknowledgement}

This work was partially supported by $\mathrm{PhD}$ project 'Application of biotechnological methods for micro-propagation of valuable ornamental trees", Ministry of Education, Youth and Science of Bulgaria and project No. 88

"Investigation of adaptive potential and application of advanced scientific approach for improving the performance of ornamental plants", Agricultural Academy, Bulgaria.

\section{REFERENCES}

Anderson W.C. 1980. Tissue culture propagation of red and black raspberries, Rubus idaeus and R. occidentalis. Acta Hort. 112: 13-20. http://www.actahort.org/books/112/112_1.htm.

Biedermann I.E.G. 1987. Factors affecting establishment and development of Magnolia hybrids in vitro. Acta Hort. 212: 625-629. http://www.actahort.org/books/212/212_104.htm.

Blaydes O.F. 1966. Interaction of kinetin and various inhibitors in the growth of soybean tissue. Physiol. Plant. 19: 748-753. DOI: 10.1111/j.1399-3054.1966.tb07060.x.

Burgos L., Ledbetter C.A. 1993. Improved efficiency in apricot breeding: Effects of embryo development and nutrient media on in vitro germination and seedling establishment. Plant Cell Tiss. Org. 35: 217-222. DOI: 10.1007/BF00037273.

Chalupa V. 1990. Micropropagation of hornbeam (Carpinus betulus $\mathrm{L}$.) and ash (Fraxinus excelsior $\mathrm{L}$.). Biol. Plant. 32: 332-338. DOI: 10.1007/BF02898493.

Callaway D.J. 1994. The world of Magnolias. Timber Press, Portland, Oregon, USA, $260 \mathrm{p}$.

Chée R., Pool R.M. 1987. Improved inorganic media constituents for in vitro shoot multiplication of Vitis vinifera. Sci. Hort. 32: 85-95. http://dx.doi.org/10.1016/0304-4238(87)90019-7. 
Coke J.E. 1996. Basal nutrient medium for in vitro cultures of loblolly pines. US Patent: 5, 534, 434.

de Oliveira L.F., Ribas L.L.F., Quoirin M., Koehler H.S., Higa A.R. 2011. Micropropagation of Pinus taeda L. via axillary buds. BMC Proc. 5 (Suppl. 7): 144. DOI: 10.1186/1753-6561-5-S7-P144.

De Proft M.P., Maene L.J., Debergh P.C. 1985. Carbon dioxide and ethylene evolution in the culture atmosphere of Magnolia cultured in vitro. Physiol. Plant. 65: 375-379. DOI: 10.1111/j.1399-3054.1985.tb08660.x.

Driver J.A., Kuniyuki A.H. 1984. In vitro propagation of Paradox walnut rootstock [Juglans hindsii $\times$ Juglans regia, tissue culture]. HortScience 19: 507-509.

Ďurković J. 2003. Regeneration of Acer caudatifolium Hayata plantlets from juvenile explants. Plant Cell Rep. 21: 1060-1064. DOI: 10.1007/s00299-003-0634-5.

Dutt M., Li Z.T., Dhekney S.A., Gray D.J. 2007. Transgenic plants from shoot apical meristems of Vitis vinifera L. "Thompson Seedless" via Agrobacterium-mediated transformation. Plant Cell Rep. 26: 2101-2110. DOI: 10.1007/s00299-007-0424-6.

Emershad R.L., Ramming D.W. 1994. Effects of media on embryo enlargement, germination and plant development in early-ripening genotypes of Prunus grown in vitro. Plant Cell Tiss. Org. 37: 55-59. DOI: $10.1007 / \mathrm{BF} 00048117$.

Fenning T.M., Gartland K.M.A., Brasier C.M. 1993. Micropropagation and regeneration of English Elm, Ulmus procera. J. Exp. Bot. 44: 1211-1217. DOI: 10.1093/jxb/44.7.1211.

Fernándes-Lorenzo J.L., Iglesias-Díaz M.I., GutiérrezAraujo O. 2000. Micropropagation of a selected rootstock of Acer palmatum. Acta Hort. 536: 347-353. http://www.actahort.org/books/536/536_40.htm.

Fett-Neto A.G., Melanson S.J., Sakata K., DiCosmo F. 1993. Improved growth and taxol yield in developing calli of Taxus cuspidata by medium composition modification. Nat. Biotechnol. 11: 731-734. DOI: $10.1038 /$ nbt0693-731.

Figlar R.B., Nooteboom H.P. 2004. Notes on Magnoliaceae IV. Blumea 49: 87-100. http://dx.doi.org/10.3767/000651904X486214.

Gabryszewska E. 1997. Wpływ tidiazuronu i cytokinin na wzrost I rozwój pędów Magnolia $\times$ soulangeana 'Alexandrina' in vitro. In: Dubert F., Skoczowski A. (Eds.), Zastosowanie kultur in vitro $\mathrm{w}$ fizjologii roślin. PAN, Kraków, pp. 79-82. [in Polish]
Gamborg O.L., Miller R.A., Ojima K. 1968. Nutrient requirements of suspension cultures of soybean root cells. Exp. Cell Res. 50: 151-158. http://dx.doi.org/10.1016/0014-4827(68)90403-5.

Gray D.J., Benton C.M. 1991. In vitro micropropagation and plant establishment of muscadine grape cultivars (Vitis rotundifolia). Plant Cell Tiss. Org. 27: 7-14. DOI: 10.1007/BF00048199.

Hammatt N., Ridout M.S. 1992. Micropropagation of common ash (Fraxinus excelsior). Plant Cell Tiss. Org. 31: 67-74. DOI: 10.1007/BF00043477.

Harada H., Murai Y. 1996. Micropropagation of Prunus mume. Plant Cell Tiss. Org. 46: 265-261.

Kamenická A. 1998. Influence of selected carbohydrates on rhizogenesis of shoots saucer magnolia in vitro. Acta Physiol. Plant. 20: 425-429. DOI: 10.1007/s11738-998-0030-4.

Kamenická A., Lanaková M. 2000. Effect of medium composition and type of vessel closure on axillary shoot production of magnolia in vitro. Acta Physiol. Plant. 22: 129-134. DOI: $10.1007 / \mathrm{s} 11738-000-0067-5$.

Kamenická A., Valka J. 1997. Cultivation and propagation of magnolias. Technical University Publishers, Zvolen, Slovakia, pp. 42-82.

Kamenická A., Kormut’ák A., Lanaková M. 2001. Establishing micropropagation conditions for three Magnolia species. Propag. Ornam. Plants 1: 41-45.

Linsmaier E.M., Skoog F. 1965. Organic growth factor requirements of tobacco tissue cultures. Physiol. Plant. 18: 100-127. DOI: 10.1111/j.1399-3054.1965.tb06874.x.

Lloyd G., McCown B. 1980. Commercially-feasible micropropagation of mountain laurel, Kalmia latifolia, by use of shoot-tip culture. Comb. Proc. Int. Plant Prop. Soc. 30: 421-427.

Marinescu L., Radomir A.M., Radu T., Teodorescu A., Fleancu M., Popescu C. 2008. Preliminary results regarding the influence of cytokinin on the micropropagation of Magnolia soulangiana Soul. Lucrări Ştiinţifice, Seria B, Horticultură 51: 601-607.

Merkle S.A., Wiecko A.T. 1990. Somatic embryogenesis in three magnolia species. J. Amer. Soc. Hort. Sci. 115: 858-860.

Miller C.O. 1978. Cytokinin modification of metabolism of p-coumaric acid by a cell suspension of soybean (Glycine max (L.) Merrill). Planta 140: 193-199. DOI: $10.1007 / \mathrm{BF} 00390248$

Ming L., Huan-Cheng M.A. 2003. The review of the asexual propagation on Magnoliaceae. J. Southwest Forestry College 23: 92-96. 
Murashige T., Skoog F. 1962. A revised medium for rapid growth and bioassays with tobacco tissue cultures. Physiol. Plant. 15: 473-497. DOI: 10.1111/j.1399-3054.1962.tb08052.x.

Nakamura K., Wakita Y., Yokota S., Yoshizawa N., Idei T. 1995. Induction of multiple shoots by shoot apex culture in Magnolia obovata Thunb. Plant Tiss. Cult. Lett. 12(1): 34-40.

Orlikowska T., Gabryszewska E. 1995. In vitro propagation of Acer rubrum cv. Red Sunset. J. Fruit Ornam. Plant Res. 3: 195-204.

Parris J.K., Touchell D.H., Ranney T.G., Adelberg J. 2012. Basal salt composition, cytokinins, and phenolic binding agents influence in vitro growth and ex vitro establishment of Magnolia 'Ann'. HortScience 47: 1625-1629.

Phelan S., Hunter A., Douglas G.C. 2009. Effect of explants source on shoot proliferation and adventitious regeneration in 10 Buddleia. Sci. Hortic. 120: 518-524. http://dx.doi.org/10.1016/j.scienta.2008.11.009.

Podwyszyńska M., Wojtania A., Gabryszewska E. 2000. Application of m-topolin for plant micropropagation. Zesz. Nauk. Inst. Sadow. Kwiac. 7: 173-180. [in Polish with English abstract]

Quoirin M., Lepoivre E. 1977. Improved media for in vitro culture of Prunus sp. Acta Hort. 78: 437-442.

Radomir A.-M. 2012. Comparative study on the in vitro multiplication potential of Magnolia stellata and Magnolia $\times$ soulangiana species. J. Hort. Forest Biotechnol. 16: 39-44.

Radomir A.-M., Radu C.M. 2008. Research on behavior of Magnolia soulangeana in the multiplication stage of 'in vitro' culture. Lucrări Ştiinţifice, Seria B, Horticultură 51: 258-261.

Rugini E.1984. In vitro propagation of some olive (Olea europaea sativa L.) cultivars with different rootability, and medium development using analytical data from developing shoots and embryos. Sci. Hortic. 24: 123-134. http://dx.doi.org/10.1016/0304-4238(84)90143-2.
Rugini E., Caricato G. 1995. Somatic embryogenesis and plant recovery from mature tissues of olive cultivars (Olea europaea L.) 'Canino' and 'Moraiolo'. Plant Cell Rep. 14: 257-260. DOI: 10.1007/BF00233645.

Santos C.V., Brito G., Pinto G., Fonseca H.M.A.C. 2003. In vitro plantlet regeneration of Olea europaea ssp. Maderensis. Sci. Hortic. 97: 83-87. http://dx.doi.org/10.1016/S0304-4238(02)00148-6.

Shanjani P.S. 2003. Nitrogen effect on callus induction and plant regeneration of Juniperus excelsa. Int. J. Agr. Biol. 5: 419-422.

Standardi A., Catalano F. 1985. Tissue culture propagation of kiwi fruit. Comb. Proc. Int. Plant Prop. Soc. 34: 236-243.

Tang H., Ren Z., Krczal G. 2000. Improvement of English walnut somatic embryo germination and conversion by desiccation treatments and plantlet development by lower medium salts. In Vitro Cell. Dev. - Pl. 36: 47-50. DOI: 10.1007/s11627-000-0011-9.

Tubesing Ch. E. 1998. Magnolias with a future: Propagation and nursery culture. In: Hunt D. (Ed.), Magnolias and their allies. International Dendrology Society, Milborne Port, pp. 193-200.

Valova M., Krajcova D., Kamenická A. 1996. Changes of mineral elements in explant of Magnolia $\times$ soulangiana Soul.-Bod. during the culturing in vitro. Folia Dendrol. 21-22: 331-339.

Yu X., Reed B.M. 1993. Improved shoot multiplication of mature hazelnut (Corylus avellana L.) in vitro using glucose as a carbon source. Plant Cell Rep. 12: 256-259. DOI: 10.1007/BF00237130.

Zefang T., Yahui H., Chao H. 2003. In vitro culture of Magnolia grandiflora. J. Hunan Agr. Univ. 29: 478-480.

Zhang C.H., Mei X.G., Liu L., Yu L.J. 2000. Enhanced paclitaxel production induced by the combination of elicitors in cell suspension cultures of Taxus chinensis. Biotechnol. Lett. 22: 1561-1564. 